\title{
KEKERASAN DI MEDIA SOSIAL PADA MAHASISWA PERGURUAN TINGGI ISLAM DALAM PERSPEKTIF GENDER
}

\author{
Harum Natasha \\ Universitas Islam Negeri Sultan Syarif Kasim Riau, Indonesia \\ barum.natasha@uin-suska.ac.id
}

\begin{abstract}
It cannot be denied that social media is an important part of life now. All positive and negative activities can be posted to social media. Apart from the goal of social media, it influences the reader so that it allows for the occurrence of abuse and violence. This study quantitatively describes the comparison of forms of violence in social media to Islamic college students and university students. The research respondents were 40 students who were taken randomly by accident technique without considering their majors and semesters. Data is collected by distributing questionnaires in the form of Likert scale. The results showed that female students used social media more than students.
\end{abstract}

Keywords : Women Violence, Social Media, Cyber World

\begin{abstract}
ABSTRAK
Tidak dapat ditolak bahwa media social menjadi bagian penting dalam kehidupan sekarang. Semua aktifitas baik positif dan negatif dapat di posting ke media sosial. Terlepas darai tujuannyaa media social mempengerauhi pembaca sehingga memungkinkana untuk terjadinya pelecehan dan kekerasan. Penelitian ini mendeskripsikan secara kuantitatif perbandingan bentuk kekerasan di media sosial pada mahasiswa dan mahasiswi perguruan tinggi Islam. Responden penelitian adalah 40 orang mahasiswa-i yang diambil secara acak dengan teknik by accident tanpa mempertimbangkan jurusan dan semesternya. Data dikumpulkan dengan menyebarkan angket berupa skala likert. Hasil penelitian menunjukkan bahwa mahasiswi lebih banyak menggunakan media sosial dibandingkan mahasiswa.
\end{abstract}

Kata Kunci: Kekerasan pada perempuan, Media Sosial, Dunia Maya

\section{PENDAHULUAN}

Pengguna internet di Indoneasia beberapa tahun terakhir adalah separuh dari jumlah total penduduk (Survey Asosiasi Penyelenggara Jaringan Internet Indonesia,2016 dalam http://tekno.kompas.com/read/2016/10/24) ).Data ini meningkat dari tahun 2014 yang hanya 88juta jiwa saja dan hal itu dipengaruhi oleh berbagai macam faktor. Salah satu faktornya yang memicu tinggi angka pengguna tersebut adalah akses internet semakin mudah dinikmati hingga ke pelosok daerah di Indonesia, karena bertambahnya pengguna 
gadget dari tahun ke tahun. Pengguna gadget saat ini tidak hanya dari kalangan atas, namun juga dari kalangan menengah ke bawah dengan memiliki telepon pintar atau smartphone. Fakta inilah yang membuat internet menjadi semakin mudah untuk diakses mulai dari usiadewasa, remaja, dan usia sekolah dasar bahkan diusia balita.

Internet digunakan dengan aplikasi yang ditawarkan banyak vendor sebagai media sosial seperti facebook, twitter, ataupun instagram. Adapula media chatting atau media khusus seperti messenger, bbm, line, dan whatsapp untuk mengobrol dengan teman lama (ataupun baru) dengan tujuan berbagi informasi, foto, video, dan bahkan menciptakan group komunitas tertentu.

Media sosial ini, mewabah pada masyarakat Indonesia dan mereka beramai-ramai membuat akun dari berbagai aplikasi yang ditawarkan vendor swasta. Akun yang semestinya hanya ditawarkan kepada pengguna berusia minimal 18 tahun ini, pada kenyataannya banyak digunakan oleh pengguna usia jauh lebih muda yang berusia 13 hingga 15 tahun (dalam http://nova.grid.id).Kemudahan mengakses media sosial bagi segala umur ini, menjadikan sarana teknologi media sosial tersebut sebagai sebuah alat yang easy-accesed bagi siapapun.Bagi pengguna media sosial khususnya perempuan merupakan suatu kebanggan memiliki teman sesama jenis dan lawan jenis, dengan mendapatkan list friends (di Facebook) yang tinggi ataupun follower (Instagram) yang banyak. Selain itu media sosial mereka gunakan untuk eksistensi diri dan media promosi tentang diri dan aktivitas hidup mereka.

Ternyata pengguna media sosial tidak hanya didominasi oleh kaum adam tetapi juga perempuan. Berikut digambarkan 10 besar urutan pengguna facebook di dunia (dalam http://tekno.kompas.com/read/2016/10/24.) yaitu : United States (145,747,320), Indonesia (32,131,200), UnitedKingdom (28,661,600), Turki $(24,368,960)$, France $(20,330,580)$, Philippines $(18,901,900)$, Mexico $(18,243,080)$, Italy $(17,914,220)$, India $(17,288,060)$, Canada $(17,142,920)$.

Di Indonesia ternyata pengguna media sosial tidak jauh berbeda antara laki-laki ( 59,4\%) dan perempuan (40.6\% ). Dari statistik di atas terlihat bahwa Indonesia menduduki peringkat ke dua terbesar sebagai pengguna facebook. Sedangkan jumlah pengguna perempuan hampir separuh dari total pengguna facebook di Indonesia. Fakta ini tentu saja merupakan bukti bahwa tingginya tingkat pengguna akun facebook di Indonesia dan ternyata separuh dari pengguna media sosial yang satu ini adalah perempuan.

Hal ini tentu menjadi sebuah kesimpulan bahwa besarnya kemungkinan terjadi tindak kekerasan pada perempuan sangat besar. Sebagian pengguna ini, kadangkala tidak menyadari 
bahwa ada banyak kemungkinan tindak kekerasan yang terjadi yang diawali dengan penggunaan media sosial.

Jika kita berbicara tentang kekerasan pada perempuan, ada banyak kasus yang terjadi baik kekerasan secara fisik maupun psikis. Ketika perempuan merasa ketidaknyaman dalam berhubungan dengan pria, maka inilah yang disebut sebagai kekerasan psikis. Seperti disebutkan dalam pasal 1 Deklarasi PBB tahun 1993 tentang PenghapusanKekerasan terhadap Perempuan (dalam http://journal.ui.ac.id/ index.php/jki/article/viewFile/1255/1160), yaitu: "Setiap tindakan berdasarkan jenis kelamin (gender based violence) yang berakibat pada penderitaan dan kesengsaraan perempuan secara fisik, seksual atau psikologis, termasuk tindakan ancaman tertentu, pemaksaan atau perampasan kemerdekaan secara sewenang-wenang, baik yang terjadi di depan umum maupun dalam kehidupan pribadi”. Hal ini berarti bahwa segala bentuk tindakan kekerasan baik fisik maupun secara psikis dan yang bersifat seksual serta ketidaknyamanan karena pemaksaan terhadap sesuatu hal banyak dialami oleh perempuan.

Secara umum Martha (2003) menyebutkan tipologi kekerasan terhadap perempuan terdiri dari : a. Kekerasan fisik yaitu berupa dorongan, cubitan, tendangan, jambakan, pukulan, cekikan, bekapan, luka bakar, pemukulan dengan alat pemukul, kekerasan dengan benda tajam, siraman air panas atau zat kimia, menenggelamkan dan penembakan. Kadangkadang kekerasan fisik ini diikuti dengan kekerasan seksual ,baik berupa serangan kealat-alat seksual (payudara dan kemaluan) maupun berupa persetubuhan paksa (pemerkosaan). Pada pemeriksaan terhadap korban akibat kekerasan fisik maka yang dinilai sebagai akibat penganiayaan adalah bila di dapati luka yang bukan karena kecelakaan, namun bekas luka itu dapat diakibatkan oleh suatu peristiwa kekerasan yang tunggal atau berulang-ulang, dari yang ringan hingga yang fatal, b. Kekerasan seksual, adalah setiap penyerangan yang bersifat seksual terhadap perempuan, baik telah terjadi persetubuhan atau tidak, baik ada atau tidaknya hubungan antara korban dan pelaku kekerasan. Pembedaan aspek fisik dan seksual dianggap perlu, karena ternyata tindak kekerasan terhadap perempuan yang bernuansakan seksual tidak sekedar melalui perilaku fisik belaka, c. Kekerasan psikologi, dibatasi pengertiannya karena sensitivisme emosi seseorang sangat bervariasi. Identifikasi akibat yang timbul pada kekerasan psikis sulit diukur. Sekalipun tindak kekerasan psikologi itu jauh lebih menyakitkan, karena dapat merusak kehormatan seseorang, melukai harga diri seseorang, merusak keseimbangan jiwa, namun kekerasan psikologis tidak akan merusak 
organ tubuh bagian dalam bahkan tindakan yang berakibat kematian. Sebaliknya, tindakan kekerasan fisik kerap menghasilkan hal yang demikian.

Defenisi kekerasan di atas tentu didasari oleh fakta yang terjadi di dunia nyata. Dengan mewabahnya penggunaan media sosial, terjadilah perpindahan tempat terjadinya tindak kekerasan yang dialami oleh para perempuan. Beredarnya gadget-gadget murah yang dapat mengakses sosial media bagi kalangan menengah ke bawah dan akses internet yang terhubung hingga pelosok nusantara adalah suatu hal yang menawarkan kemudahan bagi para pelaku dimanapun mereka berada. Penggunaan fitur-fitur media sosial bagi penggunanya bukan tidak mungkin menjadi pemicu terjadinya kekerasan pada perempuan.

Menurut Willard dalam Sartana dan Rozi Sastra (https://mediadan perempuan.wordpress.com) ada jenis-jenis kekerasan yang mungkin saja terjadi pada seseorang yang berhubungan di media sosial di dunia maya, yaitu flaming, menyampaikan kata kata pesan penuh kebencian dan amarah; harassment, melecehkan dengan mengirim pesan yang tidak pantas; denigration,melakukan pencemaran nama baik; impersonation, melakukan pelecehan terhadap seseorang dengan menggunakan identitas palsu; outing, penyebaran informasi yang tidak dikehendaki; trickery, melakukan tipu daya untuk keuntungan pribadi; exclusion, mengeluarkan individu dari interaksi sosial; dan cyberstalking, menguntit dan mengawasi korban.

Kasus flaming ada banyak terjadi di media sosial, baik di Facebook, ataupun Instagram. Terkadang sebagian orang tidak menyadari jika status yg dia posting akan dibaca oleh jutaan pengguna media sosial. Sehingga ketika merasa kecewa dan marah akan sesuatu hal, dengan ringannya mereka menuangkan ke dalam bentuk status tulisan. Mencerca ataupun mengecam orang-orang terdekat ataupun teman sendiri dengan kata-kata yang disebut sebagai kekerasan verbal. Harassment dapat saja terjadi ketika ada teman media sosial mengirimkan pesan melalui media chatting dengan isi yang tidak pantas atau melecehkan.

Data dari Komnas perempuan pada tahun 2016 (http://www.komnas perempuan.go.id) mencatat bahwa perempuan sebagai korban kekerasan di Indonesia telah mencapai 259.150 kasus yang dilaporkan dan ditangani.. Perempuan semakin merasa terpojok dengan adanya stigma dimasyarakat bahwa ia lemah, sehingga dianggap "pantas" sebagai korban kekerasan; baik secara fisik maupun psikis. Hal ini menjadi salah satu bagian dari ketidakadilan gender pada diri perempuan, dan patut untuk dicarikan solusinya.

Pertanyaan yang ingin dijawab dalam penelitian ini adalah bagaimana perbandingan terjadinya kekerasan di media sosial pada mahasiswa dan mahasiswi di perguruan tinggi 
Islam ? Apakah mahasiswi di perguruan tinggi Islam mengalami bentuk kekerasan di media sosial dibandingkan dengan mahasiswa? Bagaimana bentuk kekerasan yang terjadi?. Pertanyaan ini muncul dan menarik untuk dijawab mengingat pendidikan tinggi merupakan lembaga yang menyiapkan agent of change yaitu para mahasiswa/i yang didik sebagai pembaharu dalam masyarakat.

Logikanya ketika mahasiswa dan mahasiswi sudah menjadi korban kekerasan dari media sosial, bagaimana mungkin ia akan memberikan pencerahan di tengah masyarakat nantinya. Oleh sebab itu, menarik untuk dilihat bentuk kekerasan dalam penggunaan media sosial yang dirasakan oleh mahasiswa/i tersebut.

\section{METODE PENELITIAN}

Jenis penelitian yang digunakan adalah deskriptif kuantitatif. Penelitian ini dilakukan pada Mahasiswa/i di Universitas Islam Negeri Sultan Syarif Kasim Riau tanpa memperhitungkan jurusan dan semesternya. Responden diambil secara acak dengan teknik by accident sebanyak 40 orang yang terdiri dari 20 orang mahasiswa dan 20 orang mahasiswi .

Instrumen yang digunakan untuk mengumpulkan data adalah angket dengan skala likert. Indikator kekerasan di media sosial diambil dari teori Williar yaitu flaming, menyampaikan kata kata pesan penuh kebencian dan amarah; harassment, melecehkan dengan mengirim pesan yang tidak pantas; denigration,melakukan pencemaran nama baik; impersonation, melakukan pelecehan terhadap seseorang dengan menggunakan identitas palsu; outing, penyebaran informasi yang tidak dikehendaki; trickery, melakukan tipu daya untuk keuntungan pribadi; exclusion, mengeluarkan individu dari interaksi sosial; dan cyberstalking, menguntit dan mengawasi korban, dengan jumlah item 25 buah.

Data yang diperoleh dari isian angket diskoring dengan bobot 5 untuk jawaban selalu, 4 untuk jawaban sering, 3 untuk jawaban kadang-kadang, 2 untuk jawaban jarang dan 1 untuk jawaban tidak pernah. Skor dikelompokkan dalam distribusi frekuensi, sangat tinggi, tinggi, sedang, kurang dan sangat kurang tingkat kekerasan dalam penggunaan media sosial. Selanjutnya data diolah dengan teknik statistik persentase.

\section{HASIL PENELITIAN DAN DISKUSI}

Berdasarkan kuisioner yang peneliti sebarkan di kalangan mahasiswa/i UIN Suska Riau, digambarkan data hasil pengolahannya sebagai berikut: 


\section{Jenis Media sosial yang digunakan Responden}

Ternyata jenis media sosial yang banyak digunakan oleh responden mahasiswa dengan kesempatan memilih lebih dari 1 media sosial yang digunakan adalah whatsshap, 95\% pada mahasiswa dan 100\% pada mahasiswi. Artinya semua responden memiliki media sosial jenis whatshapp terutama pada mahasiswi. Tabel 1 berikut memperlihatkan gambaran jenis media sosial yang digunakan responden .

\section{Tabel 1 Variasi Jenis Media Sosial yang Digunakan Mahasiswa dan Mahasiswi di} Perguruan Tinggi Islam

\begin{tabular}{|l|l|l|l|l|l|}
\hline \multirow{2}{*}{ No } & \multirow{2}{*}{ Jenis media sosial } & \multicolumn{2}{|c|}{$\begin{array}{c}\text { Laki-laki } \\
(\mathrm{N}=20)\end{array}$} & \multicolumn{2}{c|}{$\begin{array}{c}\text { Perempuan } \\
(\mathrm{N}=20)\end{array}$} \\
\cline { 3 - 6 } & & $\mathrm{F}$ & \multicolumn{1}{c}{$\%$} & $\mathrm{~F}$ & \multicolumn{1}{c|}{$\%$} \\
\hline 1 & Facebook & 16 & 80 & 19 & 95 \\
\hline 2 & IG & 18 & 90 & 18 & 90 \\
\hline 3 & Twitter & 11 & 55 & 7 & 35 \\
\hline 4 & Line & 15 & 75 & 13 & 65 \\
\hline 5 & Telegram & 5 & 25 & 4 & 20 \\
\hline 6 & Whatshap & 19 & 95 & 20 & 100 \\
\hline
\end{tabular}

Berdasarkan gambaran data di atas, terlihat bahwa persentase responden mahasiswa perempuan lebih banyak menggunakan media sosial Facebook, whatshap, dibandingkan mahasiswa laki-laki. Selanjutnya data tentang bentuk kekerasan di media sosial yang terdiri dari Flamming, barassment, denigration, impersonation, outing, trickery, dan cyberstalking dapat dilihat dalam tabel 2 berikut :

Tabel 2 Bentuk Kekerasan di Media Sosial

\begin{tabular}{|c|c|c|c|c|c|c|c|c|c|c|}
\hline \multirow[b]{3}{*}{ No. } & \multicolumn{10}{|c|}{ Alternatif Jawaban } \\
\hline & \multicolumn{2}{|c|}{ Selalu } & \multicolumn{2}{|c|}{ Sering } & \multicolumn{2}{|c|}{ Kadang-Kadang } & \multicolumn{2}{|c|}{ Jarang } & \multicolumn{2}{|c|}{ Tidak Pernah } \\
\hline & $\mathbf{F}$ & $\mathbf{P}(\%)$ & $\mathbf{F}$ & $\mathbf{P}(\%)$ & $\mathbf{F}$ & $\mathbf{P}(\%)$ & $\mathbf{F}$ & $\mathbf{P}(\%)$ & $\mathbf{F}$ & $\mathbf{P}(\%)$ \\
\hline $\mathbf{A}$ & \multicolumn{10}{|c|}{ Flaming; medapatkan kata kata pesan penuh kebencian dan amarah } \\
\hline \multicolumn{11}{|c|}{ PEREMPUAN } \\
\hline 1 & 7 & 13 & 4 & 8 & 5 & 10 & 13 & 25 & 22 & 44 \\
\hline \multicolumn{11}{|c|}{ LAKI-LAKI } \\
\hline \multirow[t]{3}{*}{2} & 3 & 6 & 1 & 3 & 7 & 14 & 20 & 41 & 18 & 36 \\
\hline & \multicolumn{10}{|c|}{ Alternatif Jawaban } \\
\hline & \multicolumn{2}{|c|}{ Selalu } & \multicolumn{2}{|c|}{ Sering } & \multicolumn{2}{|c|}{ Kadang-Kadang } & \multicolumn{2}{|c|}{ Jarang } & \multicolumn{2}{|c|}{ Tidak Pernah } \\
\hline No. & $\mathbf{F}$ & $\mathbf{P}(\%)$ & $\mathbf{F}$ & $\mathbf{P}(\%)$ & $\mathbf{F}$ & $\mathbf{P}(\%)$ & $\mathbf{F}$ & $\mathbf{P}(\%)$ & $\mathbf{F}$ & $\mathbf{P}(\%)$ \\
\hline B & \multicolumn{10}{|c|}{ Harrasement: merasakan pelecehan berupa pesan yang tidak pantas } \\
\hline
\end{tabular}




\begin{tabular}{|c|c|c|c|c|c|c|c|c|c|c|}
\hline \multicolumn{11}{|c|}{ PEREMPUAN } \\
\hline 1 & 1 & 1 & 1 & 1 & 3 & 5 & 7 & 14 & 39 & 78 \\
\hline \multicolumn{11}{|c|}{ LAKI-LAKI } \\
\hline 2 & 0 & 0 & 2 & 3 & 3 & 7 & 11 & 21 & 35 & 69 \\
\hline \multirow[b]{3}{*}{ No. } & \multicolumn{10}{|c|}{ Alternatif Jawaban } \\
\hline & \multicolumn{2}{|c|}{ Selalu } & \multicolumn{2}{|c|}{ Sering } & \multicolumn{2}{|c|}{ Kadang-Kadang } & \multicolumn{2}{|c|}{ Jarang } & \multicolumn{2}{|c|}{ Tidak Pernah } \\
\hline & $\mathbf{F}$ & $\mathbf{P}(\%)$ & $\mathbf{F}$ & $\mathbf{P}(\%)$ & $\mathbf{F}$ & $\mathbf{P}(\%)$ & $\mathbf{F}$ & $\mathbf{P}(\%)$ & $\mathbf{F}$ & $P(\%)$ \\
\hline $\bar{C}$ & \multicolumn{10}{|c|}{ Denigration: pencemaran nama baik } \\
\hline \multicolumn{11}{|c|}{ PEREMPUAN } \\
\hline 1 & 0 & 0 & 0 & 0 & 3 & 6 & 18 & 36 & 29 & 58 \\
\hline \multicolumn{11}{|c|}{ LAKI-LAKI } \\
\hline \multirow[t]{3}{*}{2} & 0 & 0 & 1 & 1 & 10 & 20 & 12 & 24 & 28 & 55 \\
\hline & \multicolumn{10}{|c|}{ Alternatif Jawaban } \\
\hline & \multicolumn{2}{|c|}{ Selalu } & \multicolumn{2}{|c|}{ Sering } & \multicolumn{2}{|c|}{ Kadang-Kadang } & \multicolumn{2}{|c|}{ Jarang } & \multicolumn{2}{|c|}{ Tidak Pernah } \\
\hline No. & $\mathbf{F}$ & $\mathbf{P}(\%)$ & $\mathbf{F}$ & $\mathbf{P}(\%)$ & $\mathbf{F}$ & $\mathbf{P}(\%)$ & $\mathbf{F}$ & $\mathbf{P}(\%)$ & $\mathbf{F}$ & $\mathbf{P}(\%)$ \\
\hline $\mathbf{D}$ & \multicolumn{10}{|c|}{ Impersonation: pelecehan berupa identitas palsu } \\
\hline \multicolumn{11}{|c|}{ PEREMPUAN } \\
\hline 1 & 0 & 0 & 0 & 0 & 3 & 6 & 9 & 17 & 39 & 77 \\
\hline \multicolumn{11}{|c|}{ LAKI-LAKI } \\
\hline \multirow[t]{3}{*}{2} & 2 & 0 & 0 & 0 & 10 & 20 & 12 & 24 & 28 & 55 \\
\hline & & & & & Altern & awaban & & & & \\
\hline & & & & & Kada & Kadang & & & Tid & ernah \\
\hline No. & $\mathbf{F}$ & $\mathbf{P}(\%)$ & $F$ & $P(\%)$ & $\mathbf{F}$ & $\mathbf{P}(\%)$ & $F$ & $\mathbf{P}(\%)$ & $F$ & $P(\%)$ \\
\hline $\bar{E}$ & Outin & nyebara & orm & ri yang & $\mathrm{k} \mathrm{dik}$ & daki & & & & \\
\hline & & & & & $\overline{\mathrm{EMPI}}$ & & & & & \\
\hline 1 & 0 & 0 & 0 & 1 & 2 & 4 & 8 & 16 & 40 & 80 \\
\hline & & & & & $\overline{\mathrm{KI}-\mathrm{LA}}$ & & & & & \\
\hline 2 & 1 & 2 & 2 & 4 & 5 & 9 & 13 & 25 & 30 & 60 \\
\hline & & & & & Altern & awaban & & & & \\
\hline & & & & & Kada & Kadang & & & Tid & ernah \\
\hline No. & F & $\mathbf{P}(\%)$ & $F$ & $\mathbf{P}(\%)$ & $F$ & $\mathbf{P}(\%)$ & $F$ & P (\%) & $F$ & $\mathrm{P}(\%)$ \\
\hline $\bar{F}$ & Trick & engirim & $\overline{l n} \mathrm{~m}$ & kan tip & $\overline{\text { aya } u}$ & keuntun & $\overline{\text { prib }}$ & & & \\
\hline & & & & & $\overline{\mathrm{EMPI}}$ & & & & & \\
\hline 1 & 5 & 10 & 0 & 0 & 5 & 10 & 7 & 14 & 33 & 66 \\
\hline & & & & & KI-LA & & & & & \\
\hline 2 & 2 & 4 & 9 & 18 & 1 & 2 & 5 & 10 & 33 & 66 \\
\hline & & & & & Altern & awaban & & & & \\
\hline & & & & & Kada & Kadang & & & Tid & ernah \\
\hline No. & F & $\mathbf{P}(\%)$ & $F$ & $\mathbf{P}(\%)$ & $F$ & $\mathbf{P}(\%)$ & $F$ & P (\%) & $F$ & $\mathbf{P}(\%)$ \\
\hline $\mathbf{G}$ & Exclu & mengel & $\overline{a n ~} i$ & du dari & eraksi & & & & & \\
\hline & & & & & $\overline{\mathrm{EMPl}}$ & & & & & \\
\hline
\end{tabular}




\begin{tabular}{|c|c|c|c|c|c|c|c|c|c|c|}
\hline 1 & 0 & 0 & 0 & 0 & 1 & 2 & 12 & 23 & 38 & 75 \\
\hline \multicolumn{11}{|c|}{ LAKI-LAKI } \\
\hline 2 & 4 & 7 & 0 & 0 & 7 & 14 & 9 & 17 & 31 & 62 \\
\hline \multirow[b]{3}{*}{ No. } & \multicolumn{10}{|c|}{ Alternatif Jawaban } \\
\hline & \multicolumn{2}{|c|}{ Selalu } & \multicolumn{2}{|c|}{ Sering } & \multicolumn{2}{|c|}{ Kadang-Kadang } & \multicolumn{2}{|c|}{ Jarang } & \multicolumn{2}{|c|}{ Tidak Pernah } \\
\hline & $\mathbf{F}$ & $\mathbf{P}(\%)$ & $\mathbf{F}$ & $\mathbf{P}(\%)$ & $\mathbf{F}$ & $P(\%)$ & $\mathbf{F}$ & $\mathbf{P}(\%)$ & $\mathbf{F}$ & $\mathbf{P}(\%)$ \\
\hline $\mathbf{H}$ & \multicolumn{10}{|c|}{ Cyberstalking : dikuntit dan diawasi } \\
\hline \multicolumn{11}{|c|}{ PEREMPUAN } \\
\hline 1 & 0 & 0 & 0 & 0 & 2 & 3 & 8 & 15 & 41 & 81 \\
\hline \multicolumn{11}{|c|}{ LAKI-LAKI } \\
\hline 2 & 3 & 5 & 0 & 0 & 2 & 4 & 15 & 31 & 30 & 60 \\
\hline
\end{tabular}

Pada indikator flaming yaitu menyampaikan kata-kata penuh kebencian dan amarah terdapat perbedaan antara pria dan perempuan. Ada sebanyak 7 perempuan atau $13 \%$ yang selalu mengalami kekerasan dalam bentuk flaming sedangkan hanya ada 3 pria yang selalu mengalami kekerasan dalam bentuk yang sama. Sesuai dengan penelitian yang telah dilakukan oleh Willard dalam Sartana dan Rozi Sastra (2014) bahwa kasus flaming ada banyak terjadi di media sosial, baik di Facebook, ataupun Instagram. Terkadang sebagian orang tidak menyadari jika status yg dia posting akan dibaca oleh jutaan pengguna media sosial. Sehingga ketika merasa kecewa dan marah akan sesuatuhal, dengan ringannya mereka menuangkan ke dalam bentuk status tulisan. Mencerca ataupun mengecam orangorang terdekat ataupun teman sendiri dengan kata-kata yang disebut sebagai kekerasan verbal.

Pada indikator Harassment yaitu melecehkan dengan mengirim pesan yang tidak pantas terdapat satu perempuan atau $1 \%$ yang selalu mengalami kekerasan jenis ini. Sedangkan pada pria tidak ada mengalami kekerasan yang serupa atau 0\%. Harrasment dapat saja terjadi ketika ada teman media sosial mengirimkan pesan melalui media chatting dengan isi yang tidak pantas atau melecehkan.

Pada indikator denigration yaitu pencemaran nama baik terdapat 3 perempuan atau 6\% pada alternatif jawaban kadang-kadang yang mengalami kekerasan jenis ini. Sedangkan terdapat 2 pria yang selalu mengalami kekerasan jenis pencemaran nama baik ini. Kasus denigration juga banyak terjadi di media sosial. Mudahnya hacker membajak sebuah akun, dapat menyebabkan terjadi nya pencemaran nama baik. Atau mungkin saja menyebarkan fitnah dan isyu-isyu seperti beberapa kasus yang sampai keranah hukum. 
Pada indikator impersonation yaitu melakukan pelecehan terhadap seseorang dengan menggunakan identitas palsu terdapat 5 perempuan atau $10 \%$ yang mengaku sering mengalami kekerasan jenis ini, sedangkan 2 pria atau $4 \%$ ternyata juga mengalami hal yang serupa. Impersonation dilakukan pelaku kekerasan pada perempuan atau pria dengan menggunakan identitas palsu. Dengan menggunakan photo profile yang bukan photo dirinya dan identitas yang direkayasa, seseorang dapat melakukan pelecehan terhadap perempuanatau pria yang berteman dengannya di FB atau di media sosial lainnya.

Pada indikator Outing yaitu penyebaran informasi yang tidak dikehendaki ternyata 2 perempuan kadangkala mengalami nya atau sekitar 4\% dari sample. Sedangkan pada pria terdapat 5 orang atau 10\% yang mengalami kejadian ini di dunia media sosial. Outing terjadi pada kasus-kasus penyebaran informasi berupa photo dan video yang bersifat sangat pribadi dengan tujuan mempermalukan seseorang.

Pada indikator trickery yaitu melakukan tipu daya untuk keuntungan pribadi terdapat 5 perempuan atau 10\% dari sampel yang mengalami kekerasan jenis ini. Sedangkan pada pria terdapat 2 mahasiswa atau $4 \%$ dari sampel yang juga mengalami jenis kekerasan trickery. Trickery yaitu melakukan penipuan untuk keuntungan pribadi, bisa saja penipuan online shop ataupun jenis lainnya.

Pada indikator exclusion yaitu mengeluarkan individu dari interaksi sosial terdapat 1 perempuan pada posisi alternatif kadang-kadang. Sedangkan ternyata ada 4 pria yang selalu mengalami kekerasan jenis exclusion ini. Kasus exclusion bisa dikatakan sebagai mengucilkan seseorang dari suatu komunitas atau group.

Terakhir pada indikator Cyberstalking yaitu menguntit dan mengawasi korban dialami oleh 2 perempuan pada alternatif jawaban kadang-kadang, sedangkan terdapat 3 pria yang selalu mengalami kekerasan jenis ini. Cyberstalking yaitu mengikuti atau membuntuti seseorang lewat media sosial sebuah akun dengan tujuan mencari-cari kesalahannya, dicuri data-data nya berupa photo dan video dan diusik.

Kasus-kasus yang terjadi di dunia maya tentu juga tidak terlepas dari banyak faktor. Faktor yang paling menentukan adalah tentu dari diri perempuan ini sendiri. (https://www.brilio.net/life/4-hal-yang-bikin-perempuan-sering-jadi-korban-kejahatan-didunia-maya-151007d.html). Pertama, perempuan kadangkala ceroboh dalam hal dunia informasi dan teknologi. Seperti kasus data-data (photo dan video) yang dapat tersebar dari memory card gadget ke dunia maya. Hal ini mungkin saja terjadi jika si perempuan menjual gadget tanpa mengambil kartu memory dari HP nya. Kasus lain yaitu perempuan seringkali 
terbawa perasaan saat berkenalan dengan lawan jenis di media sosial. Ada banyak perempuan yang tertipu jutaan rupiah karena kenalan baru yang membujuk rayu dengan janji-janji cinta palsu. Ini lah salah satu modus pelaku dalam menjerat korban nya dengan melakukan PDKT terhadap perempuan, yang pada akhirnya tidak sedikit perempuan yang terbawa perasaan dengan si pelaku.

Kasus yang tak kalah marak terjadi adalah kasus terjerat cinta online hingga rela mengirim foto-foto yang tak pantas ke teman-online-barunya. Modus yang digunakan biasanya dengan alasan rindu kepada pasangan online yang berpisah jarak dan waktu. Lagi dan lagi sebagian perempuan dengan terbawa perasaan 'cinta' kepada teman pria yang sukses mendekatinya, mau saja mengirimkan photo-photo pribadinya melalui media chatting atau messenger. Ketika photo-photo ini tersebar luas di dunia maya, barulah si perempuan menyadari bahwa ia telah menjadi korban pelecehan seksual.

Kasus-kasus di atas adalah sebagian kecil kasus-kasus kekerasan yang terjadi pada perempuan. Ada banyak lagi modus-modus kekerasan yang tidak mustahil dialami oleh perempuan, ketika menggunakan media sosial. Oleh sebab itu penting bagi perempuan untuk mengetahui dan memahami, bahwa media sosial adalah tempat terbuka bagi siapa saja yang ada di lingkungannya, bahkan siapapun yang ada diseluruh dunia. Sehingga, ketika kita menggunakan media sosial maka jika tidak lebih bijak dalam memposting di media sosial, orang-orang seluruh dunia akan melihat apapun tentang segala privasi kita.

\section{KESIMPULAN DAN REKOMENDASI}

Peningkatan kebutuhan akan internet selama satu dekade ini di sebabkan oleh kemajuan teknologi internet yang telah menyebar hingga ke pelosok negeri. Juga didukung oleh mudah dan murahnya sebuah smartphone atau telefon pintar, sehingga berbagai kalangan dan usia dapat menikmati internet hanya dalam genggaman. Berbagai macam aplikasi media sosial pun menjamur bak kacang goreng menawarkan kelebihan masing-masing vendor.

Kelahiran internet dan berbagai macam media sosial ini, tentu menimbukan dampak positif dan negatif. Dampak positifnya adalah terjalinnya komunikasi dengan keluarga dan teman lama, meski berpisah jarak dan waktu. Pengguna akun media sosial dapat bertukar informasi, cerita, photo, data dan video dengan cepat dan mudah. Lewat media sosial kita juga dapat berkumpul dalam ragam komunitas dengan satu tujuan yang sama. Fitur group di dalam media sosial, mengumpukan teman-teman lama, ataupun teman baru dalam satu wadah group ataupun page-halaman khusus member tertentu sesuai aturan atau setting group 
tersebut. Page biasanya digunakan untuk menarik perhatian pemilik aku media sosial demi menarik minat mereka bergabung, susai tujuan page dibuat.

Dampak negatif dari penggunaan media sosial online adalah bahwa media ini membuka segala seluk beluk data pribadi kita ke dunia maya. Dunia yang notabene dibaca oleh jutaan penikmat internet dapat menimbulkan dan memicu kekerasan pada perempuankhsususnya. Fiur-fitur yang dimiliki sebuah media social, dimanfaat kan oleh pelaku kekerasan untuk melakukan modus-modus terntu untuk menjebak korban perempuan.

Dapat disimpulkan penggunaan media sosial yang negatif memicu terjadinya kejahatan dan kekerasan pada mahasiswi maupun mahasiswa. Kekerasan dapat bersifat fisik, dan psikis juga dapat terjadi di media sosial, seperti kekerasan verbal, atau pelecehan secara verbal. Misalnya pengiriman pesan yang tidak sesuai etika melalui media chat. Pelecehan ini juga bisa terjadi dalam berbagai bentuk lewat media sosial, diantara nya pelecehan fisik, pelecehan lisan, pelecehan isyarat, dan pelecehan emosional.

Khusus bagi mahasiswi atau perempuan, ia menjadi penentu dirinya sendiri menjadi korban kekerasan dari media sosial. Niat yang salah seperti untuk aktualisasi diri, pamer atau membohongi publik, membuat perempuan terjebak dalam perangkap menjadi korban kekerasan dari media sosial. Hal ini dikarenakan fasilitas yang tersedia di media sosial yang memberikan peluang menambah pertemanan perempuan tersebut.

Perempuan yang melakukan tindakan manipulasi (identitas dan photo) dengan aplikasi edit photo, membuat pria merasa tertarik untuk menambah akun perempuan tersebut sebagai teman di media sosialnya. Identitas palsu menjadi kedok menyembunyikan niat jahat dua pihak yang tak saling kenal, sehingga muncullah tindak kekerasan. Seperti yang disebutkan oleh Ihsan-Ketua Divisi Pengawasan Mentoring dan Evaluasi Komisi Perlindungan Anak Indonesia (https://m.tempo.co/read/news), bahwa korban biasanya terjerat oleh perhatian berlebihan dan bujuk rayu si pelaku. Perkenalan yang intens dan pelaku yang pandai memanipulasi data diri, akhirnya mengajak korban bertemu.

Perkenalan yang intens bisa terjadi dengan mulai mengklik tombol like dan simbol emosi lainnya yang berada di bagian bawah status. Pelaku juga dapat memberikan komentar pada status-satus si calon korban, demi meningkatkan durasi hubungan di dunia maya. Dengan ada nya fitur messenger sebagai media chat langsung secara pribadi pelaku juga dapat dengan mudah mendekati sang calon korban demi membangun kedekatan sehingga si perempuan mempercayai pelaku. Lewat media chat inilah obrolan dengan teman baru dapat 
berlangsung dengan cepat dan mudah, selama jaringan internet berjalan dengan baik. Dibalik kemudahan ini, para pelaku kekerasan pada perempuan memanfaatkannya untuk berkenalan dan mengobrol dengan teman perempuan yang diminatinya.

Bagi sebagian perempuan yang tidak menyadari ini, mereka dapat dengan mudahnya menjadi korban kekerasan seksual jika ia tidak berhati-hati dalam berkomunikasi di jejaring media sosial. Melalui media chatting inilah akan terjadi perkenalan singkat dan ajakan untuk bertemu ketika satu sama lain telah merasa nyaman dalam obrolan. Jika si perempuan tidak waspada maka bisa saja ia akan menjadi korban kekerasan seksual ketika ia melakukan 'kopi darat' bersama si teman baru ini (https://mediadanperempuan.wordpress.com/tag/sexualharrasment-in-social-media).

Pelecehan terhadap perempuan lebih rentan terjadi. Pelecehan yang terjadi misalnya si pelaku mengiriminya pesan yang berisi kata-kata kotor dan tak senonoh bahkan bisa jadi melecehkan fisik sang perempuan. Hal ini tentu saja akan berpengaruh pada kondisi psikologis dan emosionalnya. Sang perempuan pun bisa jadi akan makin minder dan tidak percaya diri dengan dirinya sendiri.

\section{DAFTAR PUSTAKA}

Christakis, N.A. Flower, J. H. 2010. Connected : Dasyatnya kekuatan jejaring sosial mengubah hidup kita. Diterjemahkan oleh Zia Anshor. Jakarta: Gramedia Pustaka Utama.

Martha, Elmina, Aroma. 2003. Perempuan, kekerasan, dan hukum. UII Press. Yogyakarta Sartana,dan Purna, Rozi Sastra. 2014. Potret Perempuan di Dunia Maya. Journal Kajian Gender Vol 4 no 2

http://journal.ui.ac.id/index.php/jki/article/viewFile/1255/1160

http://lifestyle.kompas.com/read/2016/04/24/150200420/Kekerasan.Pada.Perempuan.di .Dunia.Maya.Kian.Mengkhawatirkan

http://nova.grid.id/Keluarga/Anak/Di-Usia-Berapa-Anak-Boleh-Punya-Akun-MediaSosial

http://sutiatia.blogspot.co.id/2013/05/etika-menggunakan-jejaring-sosial.html http://tekno.kompas.com/read/2016/10/24/15064727/2016.pengguna.internet.di.indone sia.capai.132.juta 
http://www.komnasperempuan.go.id/lembar-fakta-catatan-tahunan-catahu-komnasperempuan-tahun-2017-labirin-kekerasan-terhadap-perempuan-dari-gang-rapehingga-femicide-alarm-bagi-negara-untuk-bertindak-tepat-jakarta-7-maret-2017/ https://deeaditya.wordpress.com/2012/01/24/kekerasan-terhadap-perempuan/ https://dikamaulana.wordpress.com/2011/07/02/pengertian-facebook-dan-sejarahfacebook/

https://id.wikipedia.org/wiki/Friendster https://m.tempo.co/read/news/2013/03/20/064468144/awas-dari-facebook-kepelecehan-seksual https://mediadanperempuan.wordpress.com/tag/sexual-harrasment-in-social-media/ https://www.brilio.net/life/4-hal-yang-bikin-perempuan-sering-jadi-korban-kejahatan-didunia-maya-151007d.html

https://www.facebook.com/notes/komunitas-jempol-like-status/manfaat-dan-efek-statusyang-di-like-ratusan-teman/107130269356526/ 